\title{
A FLEXIBILIZAÇÃO PROCEDIMENTAL EXTRAIÍA DA EXPERIÊNCIA DO CASE MANAGEMENT: UMA ANÁLISE QUANTO À PERTINÊNCIA DO INSTITUTO NO ÂMBITO DOS JUIZADOS ESPECIAIS
}

\author{
THE PROCEDURAL FLEXIBILIZATION EXTRACTED ON \\ THE CASE MANAGEMENT EXPERIENCE: AN ANALYSIS \\ ABOUT THE RELEVANCE OF THE INSTITUTE WITHIN THE \\ SPECIAL COURTS
}

RODRIGO MAIA DA FONTE Mestrando do PPGPD/Enfam. Graduado pela UFPE. Juiz federal do TRF5.

https://orcid.org/0000-0003-1132-8848

\begin{abstract}
RESUMO
Este trabalho visa avaliar em que medida a flexibilização procedimental extraída da experiência do case management pode ser aplicada no âmbito dos juizados especiais (cíveis e federais). Após exame da importância do referido instituto em relação a outros países (direito comparado), ele será avaliado à luz das normas previstas no Código de Processo Civil e nos juizados especiais, concluindo-se por uma maior pertinência da gestão processual em relação a este último subsistema.
\end{abstract}

Palavras-chave: gestão processual; flexibilidade procedimental; adaptabilidade; autonomia; juizados especiais.

\section{ABSTRACT}

The present article intends to evaluate the extent to which procedural flexibility extracted from the case management experience could be applied within the Special Courts (civil and federal). After examining the importance of the institute in relation to other countries (comparative law), it will be examined in the context of the rules arising from the Code 
of Civil Procedure and the Special Courts, concluding that the procedural management is a more pertinente strategy in relation to the latter subsystem.

Keywords: procedural management; ritual variations; adaptation; autonomy; special courts.

Recebido: 16-6-2021

Aprovado: 28-6-2021

\section{SUMÁRIO}

1 Introdução. 2 Sistemas adversarial e inquisitorial. 3 O case management. 4 O case management no novo Código de Processo Civil de 2015. 5 Gestão processual no âmbito dos juizados especiais. 6 Conclusão. Referências.

\section{INTRODUÇÃO}

Este trabalho visa avaliar em que medida (ou se) a flexibilização procedimental extraída da experiência do case management pode ser aplicada no âmbito dos juizados especiais (cíveis e federais). Isso porque embora haja abundante material nacional dispondo sobre o instituto anglo-saxônico, essa análise é, em geral, promovida à luz do Código de Processo Civil, não se percebendo a mesma generosidade doutrinária do exame da pertinência do case management em relação ao subsistema dos juizados.

O artigo será desenvolvido da seguinte maneira:

a) Com fim propedêutico, serão destacadas de maneira sintética algumas questões históricas sobre as características dos sistemas adversarial e inquisitorial, que ajudarão a contextualizar a discussão. Ao mesmo tempo, dada a especificidade do objeto deste estudo, as considerações introdutórias não deverão se estender ao ponto de desviar o foco do que se pretende enfrentar neste texto.

b) Em sequência, será apresentada a ideia geral do case management: origem histórica e como o instituto vem sendo aplicado no direito comparado, especialmente no âmbito da Europa Continental. 
c) No tópico seguinte, examinar-se-á de que maneira as ideias gerais de gestão processual influenciaram as discussões prévias à edição do Código de Processo Civil de 2015, e como elas constaram no referido diploma legal.

d) Ao final, será avaliada a pertinência do case management ao subsistema próprio dos juizados especiais.

\section{SISTEMAS ADVERSARIAL E INQUISITORIAL}

Em relação aos poderes do magistrado na condução do processo, denomina-se adversarial system o modelo caracterizado pela predominância das partes na determinação da marcha processual e na produção das provas, ao passo que o inquisitorial system, ao contrário, é o sistema no qual as mencionadas atividades recaem, de preferência, sobre o juiz. (GRINOVER, 2014)

Pode-se dizer que, em regra, os países alinhados ao common law tendem a ser, historicamente, filiados ao sistema adversarial, tendo na figura do juiz, classicamente, o expectador do debate, enquanto os ordenamentos de tradição romano-germânica (civil law) tendem a adotar o sistema inquisitorial, com juízes assumindo posição de maior protagonismo.

Isso acabaria induzindo, num primeiro exame, à justificável ideia de que os juízes aliados ao civil law, por gozarem de um ativismo superior aos que gozam os magistrados anglo-saxônicos, estariam dotados de maiores poderes de gestão e flexibilização dos procedimentos e ritos que disciplinam o processo judicial. Portanto, teriam tudo para ser o foco de estudo deste trabalho.

Curiosamente, todavia, é a vanguardista experiência anglo-saxônica de conferir maiores poderes de gerenciamento ao juiz (case management) que servirá de norte a este artigo, o qual examinará a pertinência do instituto no âmbito do direito processual brasileiro, especialmente no que concerne à possibilidade de flexibilização procedimental nos juizados especiais.

E há uma explicação para essa escolha.

Tradicionalmente, justamente porque os juízes atrelados ao tronco romano-germânico são dotados de maior protagonismo na condução 
do processo é que a gestão formal dos ritos processuais acaba tendendo a ser pré-formatada pelo legislador, conferindo pouca flexibilidade aos magistrados, como forma de evitar arbítrios.

Numa visão mais clássica, prevalecia de modo geral, no civil law, a legalidade mais rígida e estrita da marcha processual, com pouca margem para que formalmente o juiz possa adaptar o iter procedimental à complexidade e peculiaridades de cada caso. (SILVA, 2011)

Por outro lado, os sistemas processuais de tradição adversarial, muito embora convivessem com a originária passividade do juiz, acabaram por desenvolver mecanismos de variação procedimental. "Visualizando o procedimento não como garantia, mas como meio de descoberta da verdade, admitiu-se que as partes - ou o próprio juiz com o passar do tempo (case management) - pudessem adequar o instrumento ao seu fim [...]". (GAJARDONI, 2006, p. 128)

\section{O CASE MANAGEMENT}

Inspirado no que se passava nas ciências médicas, em que os tratamentos variavam de acordo com a doença e as condições pessoais dos pacientes, as cortes federais americanas desenvolveram, em meados de 1970, um programa para condução dos processos judiciais de maneira individualizada, sendo o que se entende como o embrião do judicial case management. (DUNWORTH; KAKALI, 1994 apud GAJARDONI, 2006, p. 137)

O instituto, então, passou a ser utilizado como sinônimo de "gestão processual" ou "gerenciamento" do processo. Todas essas expressões manifestam uma concepção em que o juiz assume o papel de gestor, de modo a organizar e conduzir a marcha processual no bojo de:

[...] procedimento flexível ou adaptável segundo a complexidade do caso concreto, o que pode permitir distribuição mais adequada dos recursos judiciais entre todos os processos em curso, na busca de atuação mais efetiva da duração razoável do processo. (ANDRADE, 2020, p. 184)

José Igreja Matos (2010) lembra que, em 2006, nos Estados Unidos da América, o Federal Judicial Center - instituição que assegura a formação e a investigação judiciária ao nível dos tribunais federais 
americanos - publicou uma espécie de "livro de bolso" para juízes, apresentando elementos os quais deveriam ser considerados na gestão processual, anunciando, logo na introdução, que gestão processual significa coisas diferentes para pessoas diferentes.

O mesmo autor complementa a ideia de gerenciamento processual entendendo ser a utilização, com justiça e bom senso, de todos os instrumentos à disposição dos juízes de forma a alcançar uma resolução justa, rápida e não dispendiosa do litígio.

A experiência americana é aqui lembrada por ser considerada o embrião do instituto, mas foi o ordenamento inglês que the deu multiplicidade, motivo pelo qual merece maior destaque.

Conforme antecipado em linhas passadas, sendo o modelo britânico alinhado às raízes do sistema adversarial, o magistrado condutor de um processo, tradicionalmente, atuava de maneira passiva, reativo aos estímulos das partes processuais e dos seus advogados, que figuravam como os verdadeiros gestores do processo.

Ao final da década de 90, porém, passou-se a se perceber um aumento no descontentamento do jurisdicionado inglês quanto à lentidão, complexidade e aos altos custos do processo. Segundo Barbosa Moreira (apud GAJARDONI, 2006, p. 131), em 1994, o então Lord Chacellor incumbiu o magistrado Lord Woolf de promover ativa análise em relação à justiça civil inglesa, bem como oferecer propostas para melhorar seu desempenho. Ao final, o trabalho desenvolvido pelo juiz ensejou dois relatórios sobre o acesso à justiça, o Interim Report, de 1995, e o Final Report, de 1996.

Observou-se, então, que os supracitados pontos negativos percebidos pelo jurisdicionado inglês em relação ao sistema de jurisdição cível guardavam relação, em boa parte, à exagerada subordinação da condução dos feitos judiciais à vontade dos litigantes.

Com efeito, de modo a subverter essa lógica, Lord Woolf sugeriu uma inversão dos poderes de gestão do processo, mudando das mãos das partes e seus respectivos advogados para as mãos do juiz. E essa mudança foi operada mediante lei cogente (Civil Procedure Rules CPRs), sendo possivelmente o grande diferencial do modelo inglês em relação ao case management estadunidense.

A CPR inglesa, a referida fonte normativa que disciplina as balizas do case management, expõe exemplificativamente os poderes do juiz 
inglês para gerir o processo. Destaca-se a regra 3.1(2), em que estão elencados os seguintes poderes (ALMEIDA, 2011):

a) Estender ou diminuir prazos contidos em quaisquer das normas, diretrizes ou em decisões judiciais prévias, ainda que o requerimento de extensão tenha sido feito após o prazo;

b) Retardar ou antecipar uma audiência;

c) Ordenar o comparecimento ao tribunal da parte ou de seu advogado;

d) Determinar a produção de prova por telefone ou pelo uso de qualquer outro método de comunicação oral direta, durante uma audiência;

e) Estabelecer que parte das questões ou ações envolvidas no processo, como pedidos contrapostos, sejam apreciadas em procedimentos separados;

f) Suspender total ou parcialmente o processo;

g) Reunir as questões em um único processo;

h) Julgar duas ou mais ações na mesma ocasião;

i) Estabelecer a realização de julgamento separado para qualquer das questões envolvidas no caso;

j) Decidir a ordem em que serão apreciadas as questões;

k) Determinar a exclusão de uma questão da apreciação da corte;

I) Julgar determinada ação logo após a apreciação de questão preliminar;

m) Determinar que qualquer das partes apresente uma estimativa dos custos que espera ter com o desenrolar do processo; e

n) Tomar outras decisões necessárias ao objetivo de gerir o caso com vistas ao overriding objective.

A outorga legal de maiores poderes de gestão do processo aos magistrados foi uma das razões pelas quais o case management britânico influenciou de modo mais contundente outros países da Europa Continental, que buscavam, na época, novas estratégias para valorizar 
a capacidade do juiz condutor do processo como gestor processual e organizador do procedimento, especialmente com a colaboração das partes envolvidas.

Exemplificativamente: o ordenamento de Portugal, inspirado na experiência inglesa, passou expressamente a prever o princípio da gestão processual (art. 265-B, do CPC português), enquanto na França, a criação dos "circuitos" no direito processual e a outorga de maiores poderes ao "juge de la mise en état são tentativas de tornar o julgamento das demandas mais célere e adequado às especificidades de cada caso, inserindo-se na ideia de case management". (EZEQUIEL, 2016)

Aliás, os "resultados positivos levaram que a Austrália também adotasse essa ferramenta na década de 90. Além disso, Escócia, Canadá e Nova Zelândia já tinham mecanismos de case management, de acordo com o relatório de Lord Woolf". (COSTA, 2012)

Para o presente trabalho, voltado à realidade brasileira, o que de mais relevante deve ser destacado é a ideia geral da experiência britânica de gestão processual flexível, conferindo ao juiz, em especial, o poder/dever de monitorar ativamente as fases do processo e adaptar o procedimento de acordo com os objetivos eleitos pelo sistema para tornar o feito mais célere e menos custoso.

E aqui cabe adiantar uma distinção relevante, a qual, aliás, dialogará com os tópicos a serem desenvolvidos a seguir.

Como bem destacado por Érico Andrade (2020, p. 196), não se deve confundir o aumento dos poderes do juiz na gestão processual com o aumento dos poderes instrutórios do juiz. Na gestão processual, é necessário reforçar e aumentar os poderes formais do juiz na condução e no gerenciamento processual, sem necessariamente ampliar os poderes materiais do juiz para determinar, de ofício, produção de prova.

Com efeito, não se pretende abordar aqui um cenário alinhado às ideias comumente associadas ao "ativismo judicial", mas em realidade à imagem do juiz como gestor do processo, para definir, sempre que possível em conjunto e com a participação das partes, as melhores opções procedimentais em atenção ao caso concreto, permeando tal gestão processual pela flexibilização, colaboração e proporcionalidade no uso dos recursos judiciais. 


\section{O CASE MANAGEMENT NO NOVO CÓDIGO DE PROCES- SO CIVIL DE 2015}

Assim como nos países acima citados, no Brasil a discussão sobre o poder gerencial do juiz também enriqueceu o debate quando da elaboração do Código de Processo Civil de 2015.

Numa primeira proposta de texto legal, era possível ler, no art. 107, a seguinte redação:

Art. 107. O juiz dirigirá o processo conforme as disposições deste Código, incumbindo-Ihe: [...]

$\checkmark$ - adequar as fases e os atos processuais às especificações do conflito, de modo a conferir maior efetividade à tutela do bem jurídico, respeitando sempre o contraditório e a ampla defesa.

Mais ainda, o comando normativo do art. 151, \& 10, estava assim escrito:

Art. 151. [...]

$\S 1^{\circ}$ Quando o procedimento ou os atos a serem realizados se revelarem inadequados às peculiaridades da causa, deverá o juiz, ouvidas as partes e observados o contraditório e a ampla defesa, promover o necessário ajuste.

A propósito, "a fonte de inspiração para esta nova solução legal, que visava consagrar um princípio de gestão processual, foi, segundo a própria Comissão, o processo civil inglês que se apoiou, expressamente, na regra 1.4. das CPR" (SILVA, 2011, p. 148), a qual também pode ser considerada como norma que retrata case management powers.

Todavia, iniciada a tramitação no Senado Federal do Projeto de Lei n. 166/2010, a flexibilização procedimental disciplinada nos arts. 107, $V$ e 151, § 10, do Anteprojeto do Novo CPC, foi um dos projetos mais criticados em audiências públicas, bem como nas propostas apresentadas pelos senadores e pelas diversas manifestações encaminhadas à Casa Legislativa. (OMO, 2015)

Vozes contrárias à consagração do poder de flexibilização dos procedimentos, por meio de gestão do juiz condutor do feito, alegavam, dentre outros fundamentos, que a situação implicaria insegurança jurídica e a criação de poder arbitrário em favor dos magistrados. 
Nessa sequência, ao final, a proposta inaugural do projeto foi modificada, pelo que passou a constar com o seguinte texto:

Art. 139. O juiz dirigirá o processo conforme as disposições deste Código, incumbindo-Ihe: [...]

VI - dilatar os prazos processuais e alterar a ordem de produção dos meios de prova, adequando-os às necessidades do conflito de modo a conferir maior efetividade à tutela do direito.

Segundo a versão final, o juiz deixa de ter poderes de gestão processual em sentido mais amplo, conforme inicialmente proposto, detendo, apenas, o poder de dilatar prazos processuais e o de alterar a ordem de produção dos meios de prova.

Para alguns autores, "dir-se-á que a solução final do futuro Código de Processo Civil brasileiro nasce desajustada do seu tempo. No plano do direito positivo e olhando-se para experiências estrangeiras, seria possível consagrar solução bem mais arrojada”. (SILVA, 2011, p. 148)

Todavia, a opção do legislador não ceifou por completo a aplicação da gestão processual no âmbito do direito processual civil brasileiro.

Embora se tenha optado por não consagrar expressamente o princípio da gestão processual no Código de Processo Civil de 2015, seria de rigor excessivo dizer que o espírito do case management não encontra nenhuma guarida no ordenamento nacional.

Primeiro porque a concepção anglo-saxônica de gerenciamento processual não se limita à possibilidade de flexibilização e adequação do rito às peculiaridades de cada ação - embora para este artigo seja a mais relevante. Ela também está aliada à ideia de: a) proporcionalidade; b) cooperação/colaboração; e c) busca por meios alternativos de solução de conflitos. E, nesses últimos cenários, há uma plêiade de exemplos no direito nacional.

Mais uma vez citando Érico Andrade: (2011, p. 192-193)

A proporcionalidade, na linha da melhor atuação da duração razoável do processo, permitindo maior eficiência da atuação judicial para solução das crises de direito material, encontra-se destacada nas normas fundamentais do CPC/2015, especialmente no art. 4ㄴ, ao se dispor que "as partes têm o direito de obter em prazo razoável a solução integral do mérito, incluída a atividade satisfativa", e reforçada no art. 
8, ao prever que a atuação judicial deve observar "a proporcionalidade, a razoabilidade, a legalidade, a publicidade e a eficiência".

Também a colaboração é incorporada nas normas fundamentais do CPC/2015, inclusive em expressa e explícita combinação com a eficiência da justiça, quando se prevê que "todos os sujeitos do processo devem cooperar entre si para que se obtenha, em tempo razoável, decisão de mérito justa e efetiva". Em relação à flexibilidade procedimental, apesar de não ter sido acolhida expressamente no CPC/2015, é certo que o novo Código tem muito mais abertura ou permeabilidade à flexibilidade do que o CPC/1973, pois admitiu com maior detalhamento a gestão processual pelo juiz, como se extrai do art. 139, II, IV, V, VI e IX, e acolheu, expressamente, a possibilidade de alterações procedimentais no âmbito dos negócios processuais atípicos regulados de forma ampla no art. 190.

\section{$[\ldots]$}

Além disso, a flexibilidade procedimental também pode ser extraída da conjugação, dentro do próprio processo, da técnica da solução judicial com outros meios de solução de conflitos, baseados na busca de consenso, como mediação/conciliação (art. 3으, § 3으, art. 139, V, arts. 165 a 175 do CPC/2015), em que se admite que o juiz, na condição de gestor do procedimento, possa paralisar o procedimento judicial para encaminhar a partes para centros de mediação/conciliação judiciais ou extrajudiciais, e que pode se inserir como importante ferramenta tanto de flexibilidade procedimental como de gestão processual.

Há ainda quem aponte no ordenamento outras situações em que é permitido ao julgador adaptar o procedimento de acordo com as características do feito (DIDIER JR., 2001), tais como: a) possibilidade de inversão da regra do ônus da prova, em causas de consumo (art. 6ํㅜ VIII, CDC e 373, § 1, do CPC); b) o julgamento antecipado do mérito, em que se pode abreviar o rito; c) as variantes procedimentais previstas na Lei de Ação Popular (art. 7ํ e segs.); e d) a possibilidade de o relator da ação rescisória fixar o prazo de resposta, dentro de certos parâmetros (art. 970 do CPC).

Além disso, é possível destacar as situações de gestão processual que, embora não sejam protagonizadas pelo juiz exclusivamente, são desenvolvidas em colaboração com as partes, tais como o ambiente 
negociado entre partes e magistrado quanto ao calendário do processo (art. 191 do $\mathrm{CPC}^{1}$ ) e o saneamento compartilhado (art. 357, §§ 2ำ e 3으, do $\left.\mathrm{CPC}^{2}\right)$.

\section{A GESTÃO PROCESSUAL NO ÂMBITO DOS JUIZADOS ESPECIAIS}

Os exemplos listados no tópico anterior demonstram que o direito processual brasileiro, em linhas gerais, não passou ao largo das experiências atuais no direito comparado relacionadas à concretização da gestão processual flexível e proporcional, tendo o juiz como o (ou um dos) protagonista(s), objetivando melhor empregar os recursos judiciais na busca de maior eficiência possível do sistema jurisdicional para a solução das crises de direito material, mormente a massificação de processos e a efetivação da razoável duração do processo.

No entanto, como adiantado em linhas pretéritas, o legislador, ao menos no bojo do Código de Processo Civil, rejeitou claramente a opção de conferir ao juiz mais poderes de promover a flexibilização e adaptação dos ritos e procedimentos de acordo com as peculiaridades de cada caso concreto.

\footnotetext{
Art. 191. De comum acordo, o juiz e as partes podem fixar calendário para a prática dos atos processuais, quando for o caso. \& 1ㅇ O calendário vincula as partes e o juiz, e os prazos nele previstos somente serão modificados em casos excepcionais, devidamente justificados. § 2ํ Dispensa-se a intimação das partes para a prática de ato processual ou a realização de audiência cujas datas tiverem sido designadas no calendário.

2 Art. 357. Não ocorrendo nenhuma das hipóteses deste capítulo, deverá o juiz, em decisão de saneamento e de organização do processo:

I - resolver as questões processuais pendentes, se houver;

II - delimitar as questões de fato sobre as quais recairá a atividade probatória, especificando os meios de prova admitidos;

III - definir a distribuição do ônus da prova, observado o art. 373 ;

IV - delimitar as questões de direito relevantes para a decisão do mérito;

$\checkmark$ - designar, se necessário, audiência de instrução e julgamento.

$\S 1$ Realizado o saneamento, as partes têm o direito de pedir esclarecimentos ou solicitar ajustes, no prazo comum de 5 (cinco) dias, findo o qual a decisão se torna estável.

$\S 2^{\circ}$ As partes podem apresentar ao juiz, para homologação, delimitação consensual das questões de fato e de direito a que se referem os incisos II e IV, a qual, se homologada, vincula as partes e o juiz.

§ 3은 Se a causa apresentar complexidade em matéria de fato ou de direito, deverá o juiz designar audiência para que o saneamento seja feito em cooperação com as partes, oportunidade em que o juiz, se for o caso, convidará as partes a integrar ou esclarecer suas alegações.

[...].
} 
Mas isso implica dizer que a opção do legislador em relação ao atual CPC se estende ao subsistema dos juizados especiais?

Nesse ponto, antes de responder à indagação acima, é importante rememorar a ideia consagrada no princípio da adequação, bem como apresentar a concepção do princípio da adaptabilidade, que com aquele não se confunde, embora com ele se relacione. A compreensão desses conceitos contribuirá para o desenvolvimento da temática presente neste item.

Fala-se (GAJARDONI, p. 165-187) em princípio da adequação para designar a imposição sistemática dirigida ao legislador, de modo que construa modelos procedimentais aptos à tutela especial de certas partes ou do direito material. E ainda, como corolário do primeiro, tem-se o princípio da adaptabilidade (da flexibilização ou da elasticidade processual), o qual designa a atividade do juiz de flexibilizar o procedimento inadequado ou de reduzida utilidade para melhor atendimento das peculiaridades da causa.

O primeiro (adequação), portanto, manifesta-se mediante escolha prévia e pré-determinada pelo próprio legislador em relação ao rito adequado de acordo com o objeto do processo, ao passo que o segundo (adaptabilidade) permite ao juiz, diante de um caso concreto, adaptar o rito processual às peculiaridades da causa que lhe é submetida. (DIDIER JR., 2012)

Com efeito, a flexibilização do procedimento por parte do magistrado é condição indissociável da aplicação do princípio da adaptabilidade.

Dito isso, parece ser lícito concluir que o princípio da adaptabilidade ou a flexibilização do procedimento tem acolhimento nos processos em trâmite nos juizados especiais. É que a aplicação do Código de Processo Civil em relação a esses, quando ocorre, é subsidiária, e mesmo assim apenas nos casos em que não conflita com os postulados que os fundamentam.

Com efeito, o subsistema dos juizados é regido por princípios próprios, muito mais alinhados com a concepção de maior poder de flexibilização e adaptação dos ritos ao caso concreto presente no case management. 
Na literalidade da Lei n. 9.099/1995, consta que:

Art. 2ㅇ 0 processo orientar-se-á pelos critérios da oralidade, simplicidade, informalidade, economia processual e celeridade, buscando, sempre que possível, a conciliação ou a transação.

$[\ldots]$

Art. 5ㅇ 0 juiz dirigirá o processo com liberdade para determinar as provas a serem produzidas, para apreciálas e para dar especial valor às regras de experiência comum ou técnica.

Art. 6ㅇ $\bigcirc$ juiz adotará em cada caso a decisão que reputar mais justa e equânime, atendendo aos fins sociais da lei e às exigências do bem comum.

Por sua vez, a Lei n. 10.259/2001 dispõe que:

Art. 10 São instituídos os Juizados Especiais Cíveis e Criminais da Justiça Federal, aos quais se aplica, no que não conflitar com esta Lei, o disposto na Lei n. 9.099, de 26 de setembro de 1995.

Portanto, se a realidade dos ritos abrangidos pelo Código de Processo Civil é de maior rigor formal ao procedimento escolhido pelo legislador, no bojo dos juizados a orientação é em sentido bastante díspar.

Ora, como os juizados se orientam por valores como o da simplicidade, informalidade, economia processual e celeridade, cabe ao julgador adotar as ferramentas postas à sua disposição para dar concretude a esses parâmetros. Nesse subsistema de valores próprios, pode valer, pois, a ideia de flexibilização procedimental judicial, protagonizada pelo juiz condutor do feito, e não simplesmente por força de autorização expressa na lei.

Mesmo sem haver previsão legal alguma a respeito, compete ao juiz protagonizar o gerenciamento do processo e, atento às peculiaridades do caso em concreto (objetivas e subjetivas), adaptar o rito ou iter processual para a obtenção de adequada tutela.

Aliás, há uma corrente doutrinária que enxerga no supracitado art. 6 da Lei n. 9.099/1995 uma verdadeira autorização para julgamento por equidade, chancelada, portanto, de maneira genérica, 
a flexibilização das normas processuais e materiais em favor de um julgamento mais aderente à realidade da causa. (GAJARDONI, 2006, p. 173)

Além disso, segundo o STF, o rito dos juizados especiais objetiva aumentar o acesso à justiça, seja mitigando as formalidades que dificultem o exercício desse direito fundamental, seja acelerando a marcha processual, interpretação que, aliás, é extraída do art. 98, I, da Carta Magna, que determina sejam adotados nos aludidos juizados "os procedimentos oral e sumariíssimo", devendo, portanto, "ser apreciadas cum grano salis as interpretações que pugnem pela aplicação 'subsidiária' de normas alheias ao microssistema dos juizados especiais que importem delongas ou incremento de solenidades". (BRASIL, 2014)

Com efeito, há amparo legal, doutrinário e jurisprudencial para que o julgador, ao menos no sistema dos juizados, inove no âmbito procedimental, criando ou mesclando procedimentos diversos, fundamentadamente para o fim de alcançar uma mais justa e equânime decisão, ainda que com afastamento dos padrões legislativos abstratos. (GAJARDONI, 2006, p. 174)

Em realidade, além dos argumentos apresentados acima, verificamse experiências práticas colhidas dos juizados que podem confirmar a conclusão até aqui apresentada, as quais serão demonstradas a seguir.

\subsection{O julgamento de improcedência liminar}

Até o advento do art. 285-A do CPC/73, não existia previsão normativa clara no ordenamento brasileiro autorizando que o juiz prolatasse sentença de improcedência sem oportunizar a formação do contraditório.

No âmbito dos juizados especiais, porém, buscando fazer frente à massificação das ações repetitivas e "natimortas", promovidas muitas vezes com pretensões de direito infundadas ou reiteradamente rejeitadas no mesmo juízo, os magistrados, adotando nítida atribuição gerencial e de flexibilização de procedimentos, passaram a lançar mão de um julgamento sumário de improcedência, mesmo sem audiência da parte contrária.

Segundo Caio Márcio Guterres Taranto (2009, p. 19-45), a aplicação do julgamento do mérito sem citação remonta ao ano de 2003, logo após a implantação dos juizados especiais federais, quando um grande número de demandas repetitivas foi proposto discutindo sobretudo a 
aplicação de índices de reajustes de benefícios ou de vencimento de servidores, sem que o Judiciário fosse capaz de lidar, um a um, com todos os casos novos.

Tal alteração procedimental claramente buscava otimizar o rito e trazer celeridade aos feitos, permitindo a solução imediata de milhares de ações distribuídas, que, não fosse a capacidade gerencial dos magistrados de adaptação do procedimento, aguardariam toda a formação de contraditório, num atraso sem qualquer razão prática.

Registre-se que a prática de julgamento sumário, mesmo antes da consolidação legal, já era fartamente acolhida nas turmas recursais e tribunais.

O fato é que foi a partir dessa experiência prática de flexibilização do rito, com julgamento de mérito prima facie, que acabou sendo forjado o art. 285-A, caput, do CPC/19733, atualmente com regra semelhante consagrada no art. 332 do atual $\mathrm{CPC}^{4}$.

É, pois, o primeiro importante sinal de que a flexibilização procedimental não só merecia e continua merecendo guarida no âmbito dos juizados especiais, como também, na medida do possível, deve ser estimulada, como principal ferramenta de gerenciamento processual por parte dos magistrados.

\footnotetext{
3 Art. 285-A. Quando a matéria controvertida for unicamente de direito e no juízo já houver sido proferida sentença de total improcedência em outros casos idênticos, poderá ser dispensada a citação e proferida sentença, reproduzindo-se o teor da anteriormente prolatada.

4 Art. 332. Nas causas que dispensem a fase instrutória, o juiz, independentemente da citação do réu, julgará liminarmente improcedente o pedido que contrariar:

I - enunciado de súmula do Supremo Tribunal Federal ou do Superior Tribunal de Justiça; II - acórdão proferido pelo Supremo Tribunal Federal ou pelo Superior Tribunal de Justiça em julgamento de recursos repetitivos;

II - entendimento firmado em incidente de resolução de demandas repetitivas ou de assunção de competência;

IV - enunciado de súmula de tribunal de justiça sobre direito local.

$\S 1$ ○ juiz também poderá julgar liminarmente improcedente o pedido se verificar, desde logo, a ocorrência de decadência ou de prescrição.

§ 2o Não interposta a apelação, o réu será intimado do trânsito em julgado da sentença, nos termos do art. 241.

$\S$ 3ㅇ Interposta a apelação, o juiz poderá retratar-se em 5 (cinco) dias.

$\S 4^{\circ}$ Se houver retratação, o juiz determinará o prosseguimento do processo, com a citação do réu, e, se não houver retratação, determinará a citação do réu para apresentar contrarrazões, no prazo de 15 (quinze) dias.
} 


\subsection{A Recomendação Conjunta n. 1/2015 do CNJ}

O procedimento previsto na Lei n. 9.099/1995 para as causas em tramitação nos juizados especiais cíveis, também aplicável aos juizados federais, consiste nas seguintes etapas, em resumo: apresentado o pedido, a parte ré será citada para comparecer a uma audiência conciliatória (art. 18, § 1ํ); não realizado o acordo, as partes poderão optar por submeter a questão ao juízo arbitral (art. 24); não instituído o juízo arbitral, procederse-á imediatamente à audiência de instrução e julgamento, desde que não resulte prejuízo para a defesa (art. 27); e no mesmo ato será apresentada a contestação (art. 30) e serão produzidas todas as provas (art. 28).

Ocorre que as ações contra o INSS cujo objeto é a concessão de um benefício por incapacidade (de natureza previdenciária ou assistencial), em sua maioria, reclamam a realização de perícia médica.

Dessa forma, a rigor, a apresentação de defesa por parte da autarquia previdenciária, em audiência, acabaria precedendo a entrega do laudo pericial.

Observou-se, porém, que quando o ente federal tinha em mãos o resultado do exame médico judicial previamente, a probabilidade de ofertar acordo, pondo fim à lide por transação, era muito superior.

Com a gestão dessa informação em mãos, não raro, os magistrados passaram a inverter o rito acima citado, designando de plano a perícia médica e só após o resultado desta oportunizando o contraditório para - INSS, o qual, a depender do resultado do laudo, passava a oferecer acordo com mais embasamento.

Em outras palavras, mais uma vez, os juízes dos juizados passaram a se valer de ferramentas gerenciais do processo, típicas do case management, para adaptar o rito da lei aos casos concretos, mesmo sem expressa autorização legal.

O CNJ então, em 2015, editou a Recomendação Conjunta n. 1, na qual expressamente orienta a adequação do rito sumaríssimo às peculiaridades das ações de benefícios por incapacidade que necessitam de perícia médica. 
Em especial, o referido ato normativo dispõe que:

CONSIDERANDO a necessidade de racionalizar, aperfeiçoar e uniformizar os procedimentos relativos às perícias médico-previdenciárias realizadas no âmbito do Poder Judiciário;

CONSIDERANDO a conveniência de priorizar e agilizar a instrução e o julgamento das ações de natureza previdenciária;

CONSIDERANDO a possibilidade real de incremento na conciliação em ações previdenciárias em decorrência da melhoria na qualidade e na maior uniformidade dos laudos periciais médicos produzidos em juízo

$[\ldots]$

Art. 1ำ Recomendar aos Juízes Federais e aos Juízes de Direito com competência previdenciária ou acidentária, nas ações judiciais que visem à concessão de benefícios de aposentadoria por invalidez, auxíliodoença e auxílio-acidente e dependam de prova pericial médica, que:

I - ao despacharem a inicial, considerem a possibilidade de, desde logo, determinarem a realização de prova pericial médica, com nomeação de perito do Juízo e ciência à parte Autora dos quesitos a ele dirigidos, facultando-se às partes a apresentação de outros quesitos e indicação de assistentes técnicos, e, se possível, designando data, horário e local para o ato;

II a citação do Instituto Nacional do Seguro Social (INSS) seja realizada acompanhada de laudo da perícia judicial, possibilitando a apresentação de proposta de acordo ou resposta pela Procuradoria-Geral Federal; $[\ldots]$

Com efeito, a prática, então, não só foi tolerada pelo Conselho Nacional de Justiça, como passou a ser recomendada pela instituição.

\subsection{As inspeções antecipadas}

Semelhante à experiência mencionada no item anterior ocorre com os casos de realização das inspeções judiciais de maneira antecedente à audiência una. 
O art. 35, parágrafo único, da Lei n. 9.099/1995, disciplina que no curso da audiência poderá o juiz, de ofício ou a requerimento das partes, realizar inspeção em pessoas ou coisas, ou determinar que o faça pessoa de sua confiança, que lhe relatará informalmente o verificado.

A aplicação literal do mencionado dispositivo implicaria dizer ser necessário aguardar a realização da audiência para que pudesse ser promovida a inspeção judicial.

Ocorre que em múltiplos casos dos juizados especiais, notadamente os federais, a promoção de inspeção prévia à audiência e mesmo à contestação do INSS não só permitem uma realização mais adequada desses dois atos, como também muitas vezes até dispensa a prática deles.

Cite-se como exemplo as ações em que o ponto controvertido é averiguar a presença do requisito do art. 20, § 3ㅇ, da Lei Orgânica da Assistência Social (presença da condição socioeconômica da parte), e os feitos em que o ponto controvertido é a presença da qualidade de segurado especial do autor (art. 11, VII, da Lei n. 8.213/1991).

Nas duas situações, pode ser bastante oportuno que o magistrado designe inspeção in loco, diretamente ou mediante oficiais de justiça ou peritos, cujo resultado permitirá obter informações muito mais precisas sobre o mérito de cada caso.

Em muitas vezes, inclusive, acontece o mesmo do que mencionado no subitem anterior, com proposta de acordo da autarquia federal. Quando não há transação, pode permitir o julgamento antecipado da lide sem a realização de audiências, caso as partes entendam suficientes as provas. E mesmo que o processo siga para audiência, os pontos controvertidos estarão muito mais claros, a facilitar a condução do ato.

Em outras palavras, mais uma vez a adequação do rito às peculiaridades destas ações possuem o condão de tornar a tramitação desses feitos muito mais célere, racional e econômica.

\subsection{O acolhimento das defesas "pré-elaboradas"}

A solução criativa para as relações processuais extremamente massificadas dos juizados também deu acolhimento às chamadas defesas pré-elaboradas em matérias repetitivas, como, exemplificativamente, "as de índice previdenciários, nas quais o INSS deposita defesa padrão e, em se tratando da hipótese, a Secretaria do Juizado a anexa eletronicamente 
aos autos virtuais, proferindo-se a sentença padrão, sem necessidade de citação formal." (CAVALCANTI, 2006, p. 127-144)

A prática é bastante difundida em casos que abrangem matéria exclusivamente de direito, sobre tese jurídica sedimentada pela parte ré, a exemplo de temas tributários (com defesa pré-elaborada pela Procuradoria da Fazenda Nacional), ou previdenciário (com contestações depositadas pelo INSS).

Nessas hipóteses, como acima destacado, não é raro que as instituições que promovem a defesa dos réus oficiem os juízos dos juizados solicitando o depósito das suas peças de defesa padronizadas e que são anexadas pela secretaria do juízo nos casos de idêntica matéria de direito.

Com isso, os processos cujo objeto se limita a essas matérias podem ser sentenciados a partir da distribuição, economizando-se todas as demais etapas do procedimento no primeiro grau de jurisdição, em mais uma flexibilização do rito em relação às peculiaridades desses casos concretos.

\subsection{Outros casos de adaptabilidade}

Os casos acima destacados nos subitens anteriores servem apenas para sedimentar a conclusão de que a gestão processual pelo juiz encontra terreno mais fértil no âmbito dos juizados especiais, mas não são taxativos.

Outros exemplos poderiam ser citados, como a concessão de maior delegação de atos ordinatórios (em destaque os atos que, após triagem inicial do processo pela secretaria do juízo, determinam a citação da parte contrária); a dispensa da realização de audiências nos casos que cuidem de matéria exclusivamente de direito e sendo este indisponível; a consulta de ofício pela secretaria do juízo a sistemas nacionais (ex.: CNIS - Cadastro Nacional de Informações Sociais) para auxiliar na análise de questões processuais (ex.: necessidade de citação de um litisconsorte passivo necessário nas ações de desdobramento de pensão); remessa antecipada (no início do processo) dos autos à contadoria, para apurar a existência de IRT (índice de reajuste do teto) e o valor da causa nas ações denominadas "buraco negro"; e expedição de precatório/RPV como forma anômala de cumprimento de obrigações de fazer nas demandas de saúde. 


\section{CONCLUSÃO}

Como visto, a necessidade de apresentar soluções justas, rápidas e não dispendiosas aos litígios, que cresciam acentuadamente, fizeram com que as experiências do case management anglo-saxônico inspirassem diversos ordenamentos jurídicos, especialmente na Europa Continental.

No Brasil, embora com a vigência do Código de Processo Civil de 2015 se tenha optado por não consagrar expressamente o princípio da gestão processual - ao menos não de maneira mais aberta e flexível -, é possível extrair de diversas passagens do referido diploma legal exemplos que nos aproxima do instituto do common law.

Mas certamente o são os juizados especiais os subsistemas mais alinhados às raízes do gerenciamento processual, no âmbito do qual se confere maior poder de adaptabilidade ao juiz, que passa a ter mais possibilidades de promover a flexibilização procedimental, de sorte a tornar o processo mais célere e menos custoso, além de fazer frente à massificação de ações que ali tramitam. 


\section{REFERÊNCIAS}

ALMEIDA, Diogo Assumpção Rezende de. O case management inglês: um sistema maduro? Revista Eletrônica de Direito Processual, Rio de Janeiro, v. 7, n. 7, 2011. Disponível em: https://www.e-publicacoes.uerj.br/ index.php/redp/article/view/21127/15217. Acesso em: 15 out. 2020.

ANDRADE, Érico. Gestão processual flexível, colaborativa e proporcional: cenários para implementação das novas tendências no CPC/2015. Revista da Faculdade de Direito da UFMG, Belo Horizonte, n. 76, p. 183-212, jan./jun. 2020. Disponível em: https://revista.direito. ufmg.br/index.php/revista/article/view/2065/1929. Acesso em: 29 dez. 2020.

BRASIL. Supremo Tribunal Federal (Tribunal Pleno). ARE 648629. Relator: Min. Luiz Fux, 24 de abril de 2013. DJe, Brasília, n. 69, 7 abr. 2014.

CAVALCANTI, Francisco de Queiroz Bezerra. Considerações acerca da improcedência liminar nas ações repetitivas: um estudo sobre a compatibilidade do artigo 285-A, do Código de Processo Civil, com o sistema processual vigente. Direito Federal: Revista da Ajufe, Brasília, v. 23, n. 85, p. 127-144, jul./set. 2006.

COSTA, Henrique Araújo. Os poderes do juiz na Inglaterra e no Brasil: estudo comparado sobre os case management powers. 2012. Tese (Doutorado) - Pontifícia Universidade Católica de São Paulo, 2012.

DIDIER JR., Fredie. Curso de direito processual civil. Salvador: Juspodivm, 2012. v. 1.

DIDIER JR., Fredie. Sobre dois importantes, e esquecidos, princípios do processo: adequação e adaptabilidade do procedimento. Revista Diálogo Jurídico, Salvador, v. 1, n. 7, out. 2001. Disponível em: http://www.abdpc.org.br/abdpc/artigos/Fredie\%20Didier_3_-\%20 formatado.pdf. Acesso em: 2 maio 2021.

EZEQUIEL, Caroline Dal Poz. Os circuits do direito processual francês e a possibilidade de sua adoção pelo ordenamento jurídico brasileiro. Revista de Processo, São Paulo, v. 255, maio 2016. 
GAJARDONI, Fernando da Fonseca. Flexibilidade procedimental: um novo enfoque para o estudo do procedimento em matéria processual. 2006. Tese (Doutorado em Direito) - Universidade de São Paulo, 2006.

GAJARDONI, Fernando da Fonseca; SOUZA, Maurício Bearzotti de. Os princípios da adequação, da adaptabilidade e da flexibilização procedimental pelo juiz no novo CPC. Revista do Tribunal Superior do Trabalho, São Paulo, SP, v. 82, n. 3, p. 165-187, jul./set. 2016. Disponível em: https://hdl.handle.net/20.500.12178/96971. Acesso em: 28 dez. 2020.

GRINOVER, Ada Pellegrini. Verdade real e verdade formal? Um falso problema. São Paulo: IBDP, 2014. Disponível em: http://www. direitoprocessual.org.br/aid=37.html?shop_cat=1_5\&shop_detail=32. Acesso em: 29 dez. 2020.

MATOS, José Igreja. A gestão processual: um radical regresso às raízes. Julgar [s. I.], n. 10, p. 123-137, 2010. Disponível em: http://julgar.pt/ wp-content/uploads/2015/10/123-137-Gest\%C3\%A3o-processual.pdf. Acesso em: 28 out. 2020.

OMO, Taynara Tiemi. A flexibilização do procedimento e sua abordagem na tramitação legislativa do novo Código de Processo Civil. Revista Eletrônica de Direito Processual: REDP, Rio de Janeiro, v. 9, n. 16, jul./ dez. 2015. Disponível em: https://www.e-publicacoes.uerj.br/index.php/ redp/article/view/18733/14323. Acesso em: 29 dez. 2020.

SILVA, Paula Costa e. Legalidade das formas de processo e gestão processual ou as duas faces de Janus. Revista de Informação Legislativa, Brasília, v. 48, n. 190, p. 137-149, abr./jun. 2011. Disponível em: https://www2.senado.leg.br/bdsf/bitstream/handle/ id/242924/000929312.pdf?sequence=3. Acesso em: 29 dez. 2020.

TARANTO, Caio Márcio Guterres. Fechamento sistêmico do procedimento dos juizados especiais federais pelos precedentes jurisdicionais. Revista da SJRJ, Rio de Janeiro, n. 24, p. 19-45, 2009. Disponivel em: https://www.jfrj.jus.br/revista-sjrj/edicao/revista-da-sjrjno-24-juizados-especiais. Acesso em: 7 jan. 2021. 
ENFAM 